\title{
Internal fixation vs conservative treatment for displaced distal radius fractures: a meta-analysis of randomized controlled trials
}

\author{
Guang-Shu Yu, M.D., ${ }^{1}$ Yan-Bin Lin, M.D., ${ }^{1}$ Li-Sheng Le, M.D., ${ }^{2}$ \\ Mei-Feng Zhan, M.D., ${ }^{3}$ Xiao-Xiang Jiang, M.D. ${ }^{4}$
}

\begin{abstract}
${ }^{1}$ Department of Orthopaedics and Traumatology, Fuzhou The $2^{\text {nd }}$ Hospital of Xia Men University, Fu Zhou, Fujian-China
${ }^{2}$ Department of Orthopaedics and Traumatology, Mawei Branch of Fuzhou The $2^{\text {nd }}$ Hospital, Fu Zhou, Fujian-China

${ }^{3}$ Department of Orthopaedics and Traumatology, Luoyuan County Hospital, Luo Yuan, Fujian-China

${ }^{4}$ Graduate School, Fujian University of Traditional Chinese Medicine, Fu Zhou, Fujian-China
\end{abstract}

\begin{abstract}
BACKGROUND: The aim of the present study was to compare clinical outcomes of internal fixation and conservative approach in the treatment of displaced distal radius fractures.

METHODS: Reports of studies were retrieved from the PubMed, Cochrane Library, EMBASE, BIOSIS, Ovid, CNKI, and Wanfang Data databases, as well as manually. Methodological quality of the trials was critically assessed, and relevant data were extracted. Review Manager (RevMan) meta-analysis software (version 5.0; Cochrane Collaboration, London, UK) was used for data analysis.

RESULTS: A total of 10 randomized controlled trials, which included 653 patients, were eligible for inclusion in the present metaanalysis, 7 of which were in English, and 3 of which were in Chinese. The trials had medium risk of bias. Results of meta-analysis showed that patients undergoing conservative treatment for distal radius fractures had better restoration of pronation (MD=I.80, $95 \%$ confidence interval $[\mathrm{Cl}]=0.18-3.42, p=0.03$; heterogeneity $p=0.17,12=43 \%$ ), but shorter restoration of radial length (MD=2.62, $95 \%$ $\mathrm{Cl}=1.47-3.76, \mathrm{p}<0.0000 \mathrm{I}$; heterogeneity $\mathrm{p}=0.02,12=73 \%$ ). Wrist range of motion other than pronation, grip strength, radiographic parameters other than radial length, and rates of complications were not significantly different between the 2 treatments.
\end{abstract}

CONCLUSION: Very few clinical differences were found between results of internal fixation and conservative treatment for displaced distal radius fractures. Best course of of treatment must be determined based on concrete conditions.

Keywords: Conservative treatment; distal radius fracture; internal fixation; meta-analysis.

\section{INTRODUCTION}

Distal radius fractures are one of the most common types of fractures, and the pediatric and elderly populations are at greatest risk. ${ }^{[I]}$ Most distal radius fractures can be treated by closed reduction and plaster immobilization, which often

Address for correspondence: Yan-bin Lin, M.D.

Department of Orthopaedics and Traumatology, Fuzhou the $2^{\text {nd }}$ Hospital of Xia Men University, No: 47, Shang-Teng Road, Cang-Shan District, Fuzhou, People 350007 Fuzhou, China Tel: +86-13960743906 E-mail: 812953900@qq.com

Qucik Response Code

Ulus Travma Acil Cerrahi Derg

2016;22(3):239-24।

doi: $10.5505 /$ tjtes.20I5.05995

Copyright 2016

TJTES leads to satisfactory outcome. ${ }^{[2]}$ However, the elderly are increasingly likely to choose a more active and independent lifestyle, requiring increased limb function. As a result of which, comprehension of nonsurgical and surgical treatment is evolving, with recently developed methods of fixation. ${ }^{[3,4]}$

Redisplacement is a risk of conservative treatment of distal radius fractures, because parking position accuracy is sometimes impossible to attain. Subsequently, the opportunity to perform early postoperative functional exercise may be lost, resulting in likelihood of wrist ankylosis and limited activity. A trend toward selection of open reduction and internal fixation has been identified. ${ }^{[5]}$

Using diverse document retrieval systems, many meta-analyses of external fixation vs internal fixation for distal radius fractures were found that identified significantly better functional outcome of internal fixation. ${ }^{[6-8]}$ Only one meta-analy- 
sis supported the use of external fixation. ${ }^{[9]}$ Choices of treatment have been compared in many randomized controlled trials (RCTs). However, these have lacked systemic evaluation.

In order to clarify whether internal fixation is superior to conservative treatment of distal radius fractures, in terms of functional outcome and on the basis of new evidence, the present meta-analysis was conducted, incorporating reports of all relevant RCTs available in Chinese or English. Sub-group analyses were presently performed on the basis of range of motion and radiological outcome.

\section{MATERIALS AND METHODS}

\section{Search Strategy}

Reports of studies were retrieved (from the earliest records available to those dated August I, 20I4) from the PubMed, Cochrane Library, EMBASE, BIOSIS, Ovid, CNKI, and Wanfang Data databases, as well as manually. The following search terms were used: (distal radial fractures or distal radius fractures or fracture radius or fractures radius or fractures of distal radius or Colles' fractures or Smith's fractures or wrist injuries) and (internal fixation or plate or plating or percutaneous pinning or percutaneous crossed-pin fixation or percutaneous pin fixation) and (conservative treatment or plaster cast or casting). The search was limited to human subjects and RCTs published in Chinese or English.

\section{Inclusion and Exclusion \\ Inclusion Criteria}

Studies were considered acceptable for inclusion if they met the following criteria: (I) population, patients with unstable distal radius fracture that had occurred less than 14 days previously or axial compression $>2 \mathrm{~mm}$ or dorsal angulation $>20^{\circ}$, (2) study design, randomized controlled trials, (3) comparison intervention, internal fixation vs conservative treatment for distal radius fractures, (4) outcome measures, clinical results, radiological outcomes, and complication.

\section{Exclusion Criteria}

Trials were excluded if they (I) were abstracts, letters, or meeting proceedings, (2) used repeated data or the data could not be obtained by calculation, and (3) if original documents of experimental design were not precise.

\section{Data Extraction and Outcome Measures}

Inclusion decisions were independently made by 2 authors according to eligibility criteria, and were recorded on a specially developed form. Differences in opinion between authors were resolved by discussion, and a third author was consulted if necessary. The following data were recorded for each study (I) first author's name, methods of treatment, gender distributions, average age, duration of follow-up, year of publication, country of origin, revised Jadad score, (2) wrist range of motion (wrist flexion and extension, forearm pronation, and supination, and radial and ulnar deviation), (3) grip strength, (4) radiographic parameters of dorsal angulation, radial length, radial inclination, and ulnar variance, (5) rates of complications, etc.

\section{Risk-of-Bias Quality Assessment and Quality Scoring}

Risk-of-bias assessment was performed in accordance with

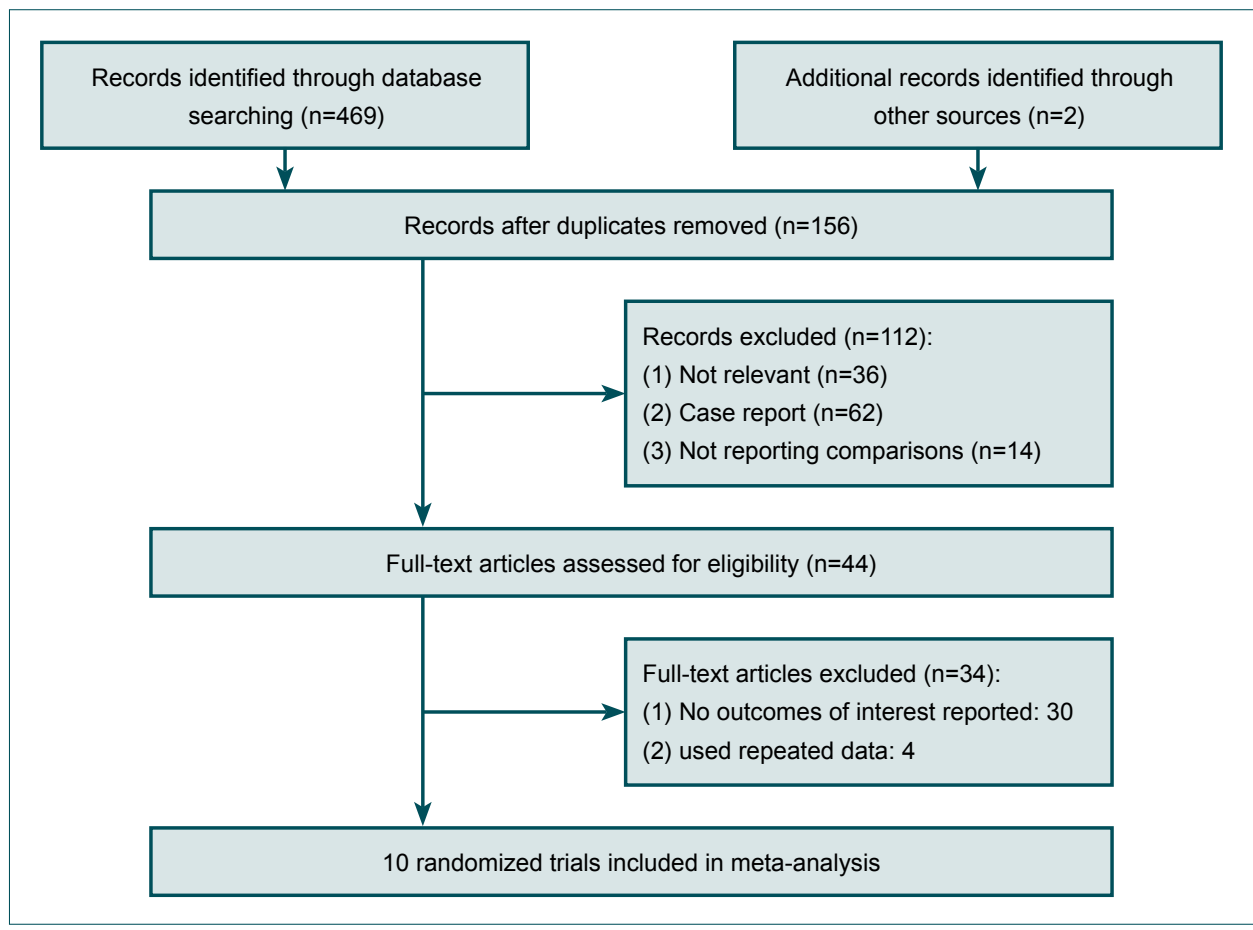

Figure 1. Selection process for randomized controlled trials included in meta-analysis. 
guidelines outlined in the Cochrane Handbook for Systematic Reviews of Interventions (version 5.0), with the Cochrane Collaboration's tool for assessing risk of bias. Studies were classified using 3 categories, as follows: yes (low risk of bias; all criteria met), unclear (moderate risk of bias; I or more criteria partly met), and no (high risk of bias; I or more criteria not met). Each RCT was independently assessed by 2 reviewers. Any disagreements were resolved by discussion and consensus.

Quality scoring for each trial was performed using modified Jadad scale, an 8-item scale designed to assess randomization, blinding, withdrawals and dropouts, inclusion and exclusion criteria, adverse effects, and statistical analysis.

(I) Was the study described as randomized? Yes: +I; No: 0.

(2) Was the method of randomization appropriate? Yes +1 ; No: -I; Not described: 0. (3) Was the study described as blinded? Yes: + I; No: 0.

(4) Was the method of blinding appropriate? Yes: +I; No: - I; Not described: 0.

(5) Was there a description of withdrawals and dropouts? Yes: + I; No: 0.

(6) Was there a clear description of the inclusion/exclusion criteria? Yes: + I; No: 0.

(7) Was the method used to assess adverse effects described? Yes: + I; No: 0.

(8). Was the method of statistical analysis described? Yes: +1 ; No: $0 .^{[10]}$

The score of each article ranged from 0 (lowest quality) to 8 (highest quality). Scores of 4-8 denoted good to excellent quality, and $0-3$ denoted poor to low quality.

\section{Statistical Analyses}

Data were independently entered into the Review Manager (RevMan) meta-analysis software program (version 5.0; Cochrane Collaboration, London, UK) by 2 authors. Relative risk (RR) was used as the summary statistic for dichotomous outcomes, and weighted mean difference was used for continuous outcomes, both with $95 \%$ confidence interval $(\mathrm{Cl})$. A fixed-effects model was used when there was no statistical evidence of heterogeneity; otherwise, a random-effects model was used. If presence of heterogeneity was found, it was indication that study population, treatment, outcome measures, and methodologies should be checked to determine the source of heterogeneity. If it could not be quantitatively synthesized, or event rate was too low to be measured, it was indication that this should be described in qualitative evaluation. Publication bias was assessed using funnel plots.

\section{RESULTS}

\section{Studies Included in Meta-Analysis}

A total of 469 potentially eligible studies were identified by the database. After browsing by title, then reading the abstract and the entire text, 10 published studies met all inclusion criteria and proved eligible for the present investigation. These studies collectively included 653 patients ( 340 of whom received conservative treatment, and 313 of whom received internal fixation). In the present meta-analysis, 7 studies were reported in English and 3 were reported in Chinese, ${ }^{[1-20]}$ and 9 studies included only adult patients (Fig. I).

Quality was evaluated using modified Jadad score, the total score of which was 8 points. Studies that received 3 points or fewer were considered low-quality (level B), and those that received 4 points or more were considered high-quality (level A). Seven studies qualified as level A, and 3 qualified as level B. Risk-of-bias analysis revealed that all trials were of medium risk of bias (Fig. 2).

\section{Meta-Analysis}

\section{Meta-Analysis of Clinical Results}

Data for flexion, extension, pronation, supination, and radial and ulnar deviation were pooled among 3 studies. Analysis of

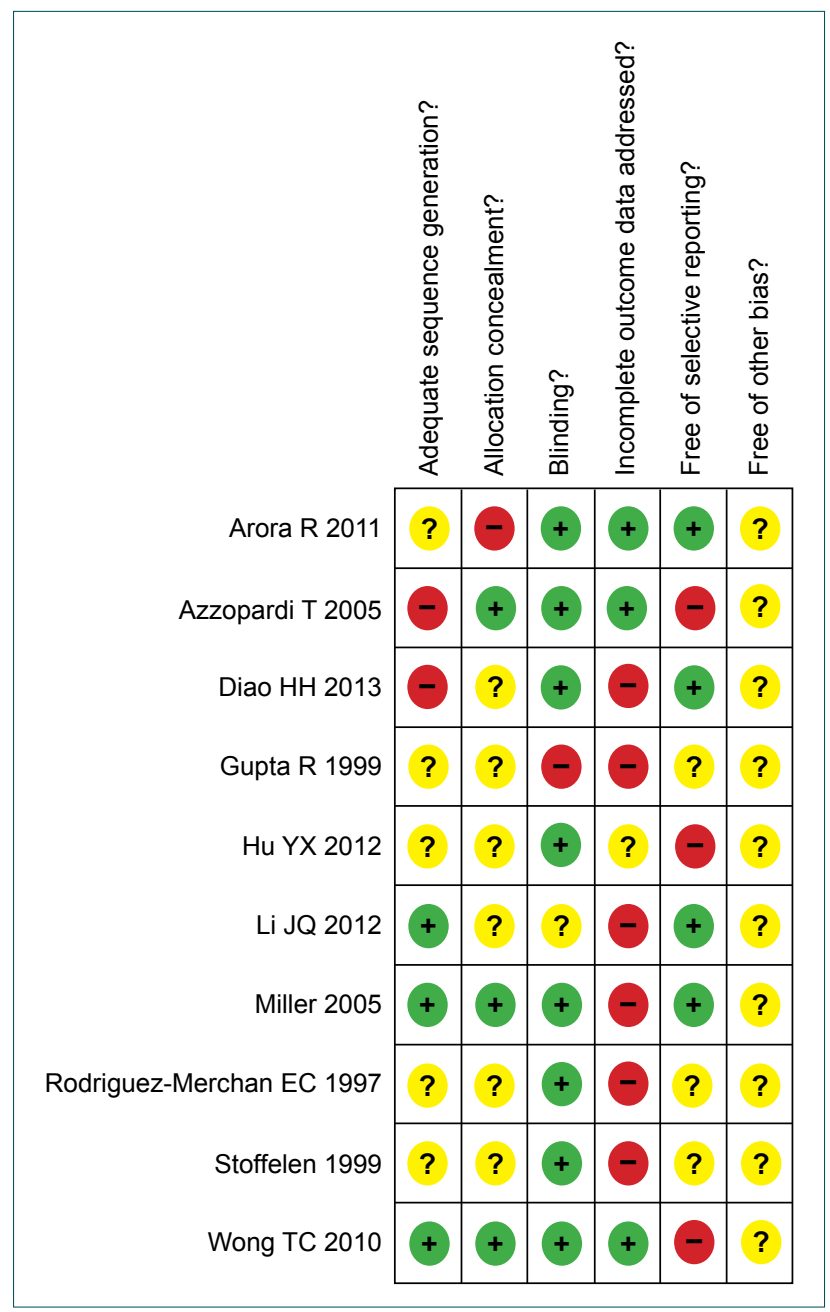

Figure 2. Risk-of-bias summary: Author judgments regarding each risk-of-bias item for included studies. 


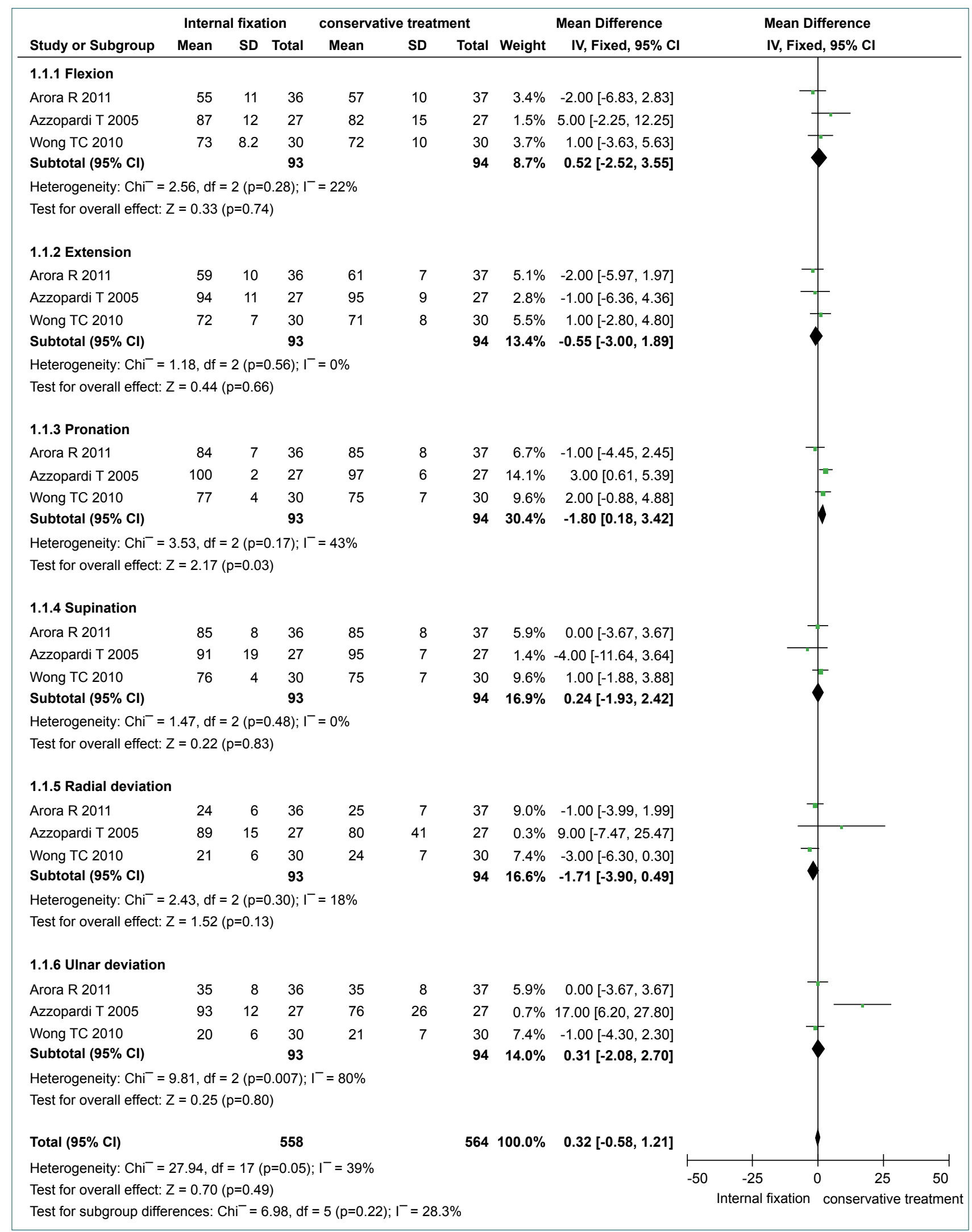

Figure 3. Table and forest plot illustrating meta-analysis of range of motion.

the data revealed no significant difference in range of motion, but pronation was significantly better among patients who received conservative treatment (flexion $\mathrm{MD}=0.52,95 \% \mathrm{Cl}=$ $-2.52-3.55, p=0.74$; heterogeneity $p=0.28,12=22 \%$; exten- 


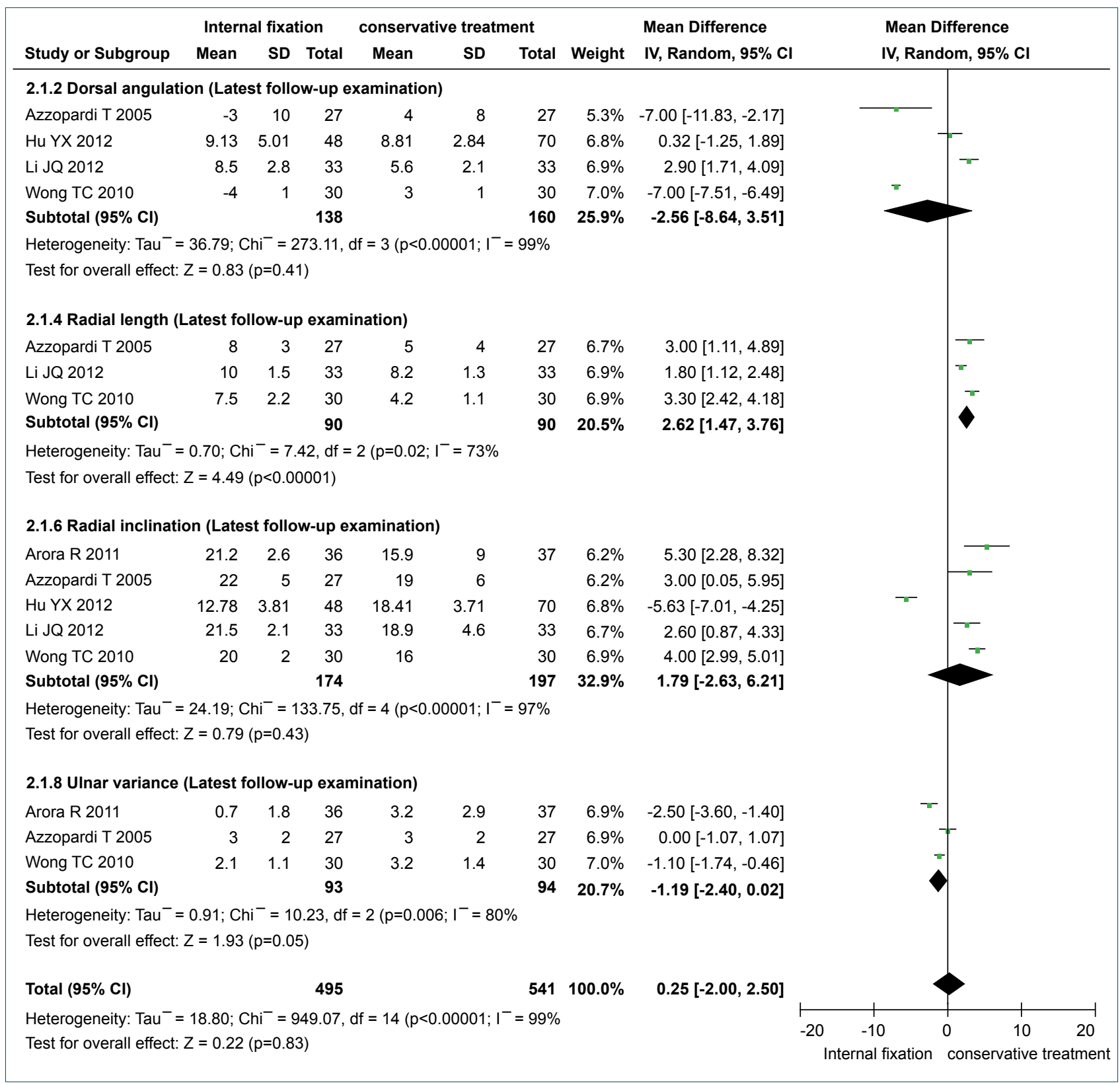

Figure 4. Table and forest plot illustrating meta-analysis of radiological outcomes.

sion $\mathrm{MD}=-0.55,95 \% \mathrm{Cl}=-3.00-1.89, \mathrm{p}=0.66$; heterogeneity $\mathrm{p}=0.56,12=0 \%$; pronation $\mathrm{MD}=1.80,95 \% \mathrm{Cl}=0.18-3.42$, $p=0.03$; heterogeneity $P=0.17,12=43 \%$; supination $M D=0.24$, $95 \% \mathrm{Cl}=-1.93-2.42, \mathrm{p}=0.83$; heterogeneity $\mathrm{p}=0.48,12=0 \%$; radial deviation $\mathrm{MD}=-1.71,95 \% \mathrm{Cl}=-3.90-0.49, \mathrm{p}=0.13$; heterogeneity $p=0.30,12=18 \%$; ulnar deviation $M D=2.86,95 \%$ $\mathrm{Cl}=-3.33-9.05, \mathrm{p}=0.37$; heterogeneity $\mathrm{p}=0.007,12=80 \%)(\mathrm{Fig}$. 3).

Grip strength was reported in 2 studies that were found to be statistically heterogeneous $(p=0.08,12=67 \%)$, and a random-effects model was used. Meta-analysis showed that no statistically significant between-group difference in grip strength was found $(\mathrm{MD}=1.58,95 \% \mathrm{Cl}=-2.24-5.93, \mathrm{p}=0.42)$.

\section{Meta-Analysis of Radiological Outcomes}

Dorsal angulation was reported in 4 studies (heterogeneity $\mathrm{p}<0.00001,12=99 \%)$. A random-effects model was used and suggested that there was no significant difference in dorsal angulation between the treatment groups (MD $=-2.56,95 \%$ $\mathrm{Cl}=-8.64-3.5 \mathrm{I}, \mathrm{p}=0.4 \mathrm{I}$ ). Radial length was reported in 3 studies, and a random-effects model suggested that radial length of the conservative treatment group was longer than that of the internal fixation group $(M D=2.62,95 \% \mathrm{Cl}=1.47-$ 3.76, $p<0.00001$; heterogeneity $p=0.02,12=73 \%$ ). Radial inclination was reported in 5 studies, among which there was no significant between-group difference $(M D=1.79,95 \% \mathrm{Cl}=$ $-2.63-6.21, p=0.43$; heterogeneity $p<0.00001,12=97 \%$ ). Ulnar variance was reported in 3 studies (heterogeneity $p=0.006$, 


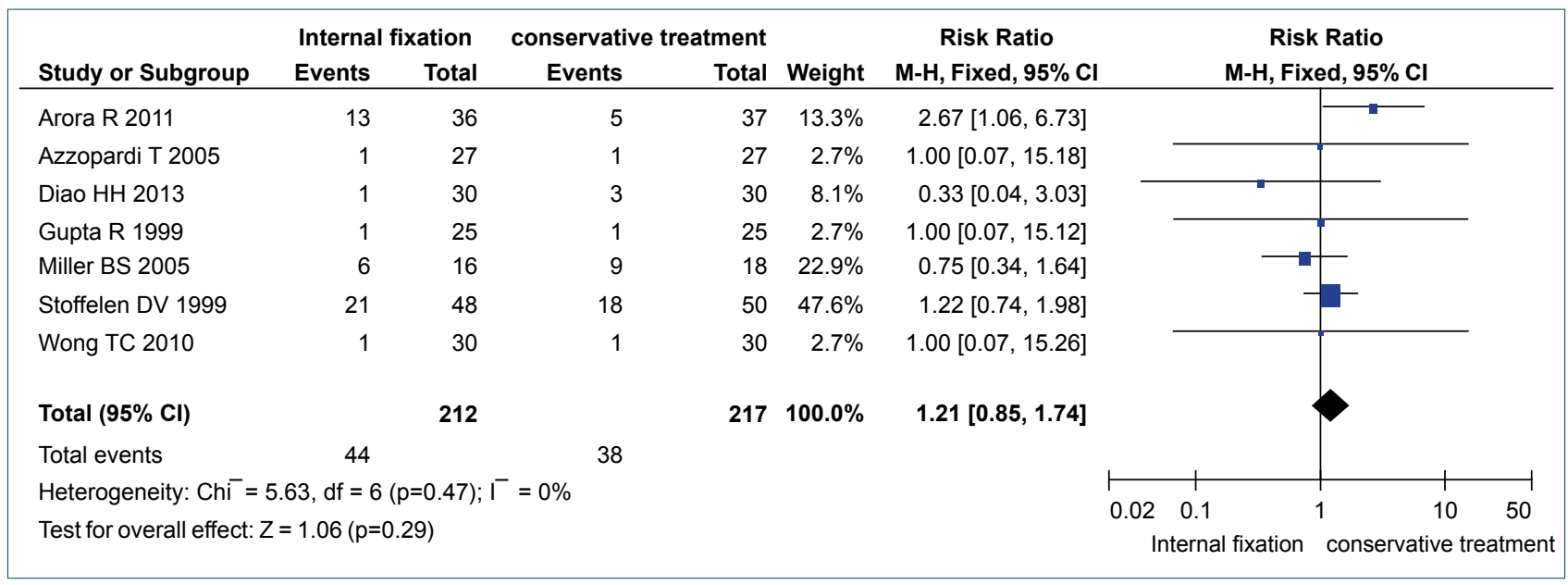

Figure 5. Table and forest plot illustrating meta-analysis of rate of complications.

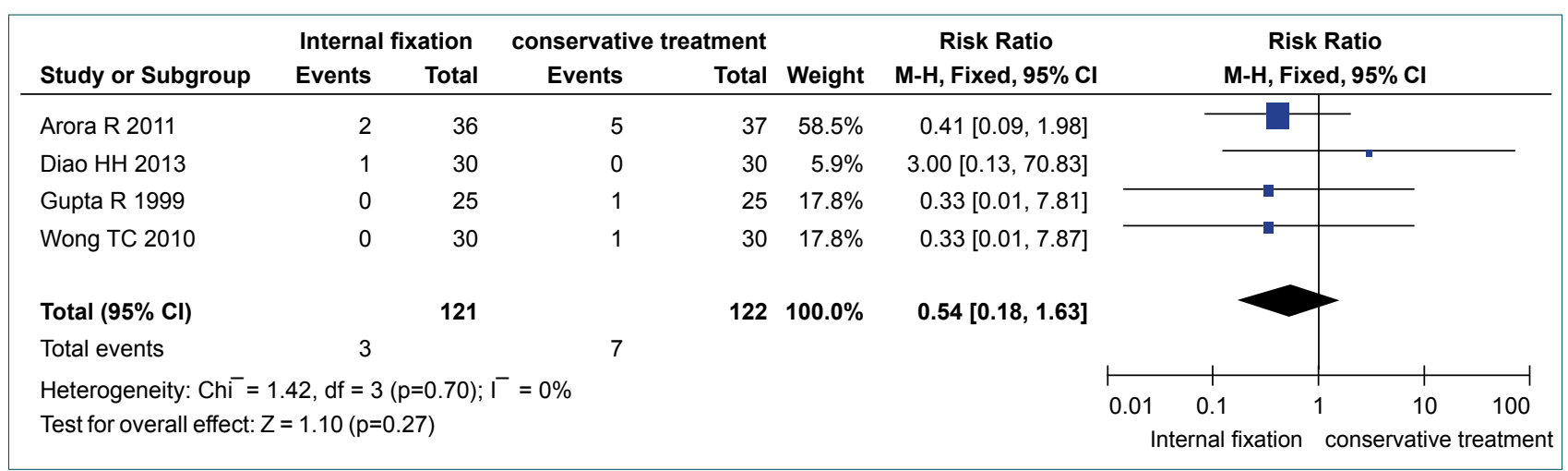

Figure 6. Table and forest plot illustrating meta-analysis of complex regional pain syndrome.

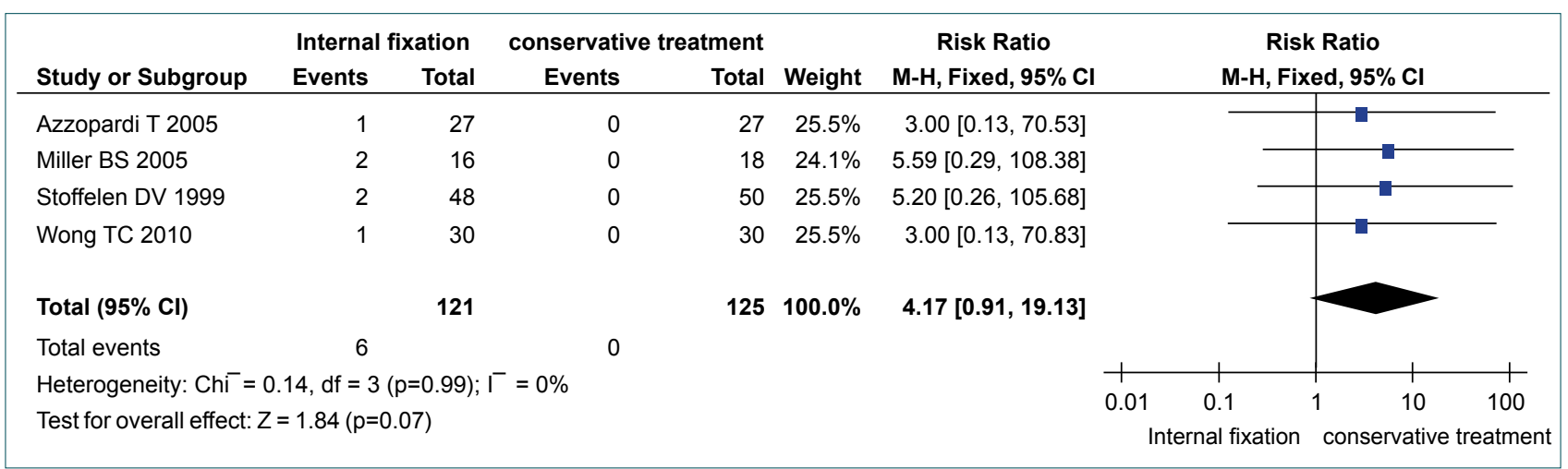

Figure 7. Table and forest plot illustrating meta-analysis of infection.

$12=80 \%)$. A random-effects model suggested no significant between-group difference $(\mathrm{MD}=-\mathrm{I} .19,95 \% \mathrm{Cl}=-2.40-0.02$, $\mathrm{p}=0.05$ ) (Fig. 4).

\section{Meta-Analysis of Complications}

Data on rate of complications were pooled from the 10 studies found to be statistically heterogenous ( $p=0.47,12=0 \%)$. A fixed-effects model suggested that there was no significant between-group difference in rate of complications $(R R=1.18$, $95 \% \mathrm{Cl}=0.82-1.70, \mathrm{p}=0.37)$. Complex regional pain syndrome was one of the most frequently reported complications, and no significant between-group difference was found $(R R=0.54$, $95 \% \mathrm{Cl}=0.18-1.63, \mathrm{p}=0.27$; heterogeneity $\mathrm{p}=0.70,12=0 \%$ ). Infection was one of the other most frequently reported complications, and no significant between-group difference was found $(\mathrm{RR}=4.17,95 \% \mathrm{Cl}=0.91-19.13, \mathrm{p}=0.07$; heterogeneity $\mathrm{p}=0.99,12=0 \%)($ Figs. $5-7)$.

\section{Publication Bias}

Some quality scoring was low, which made publication bias a 


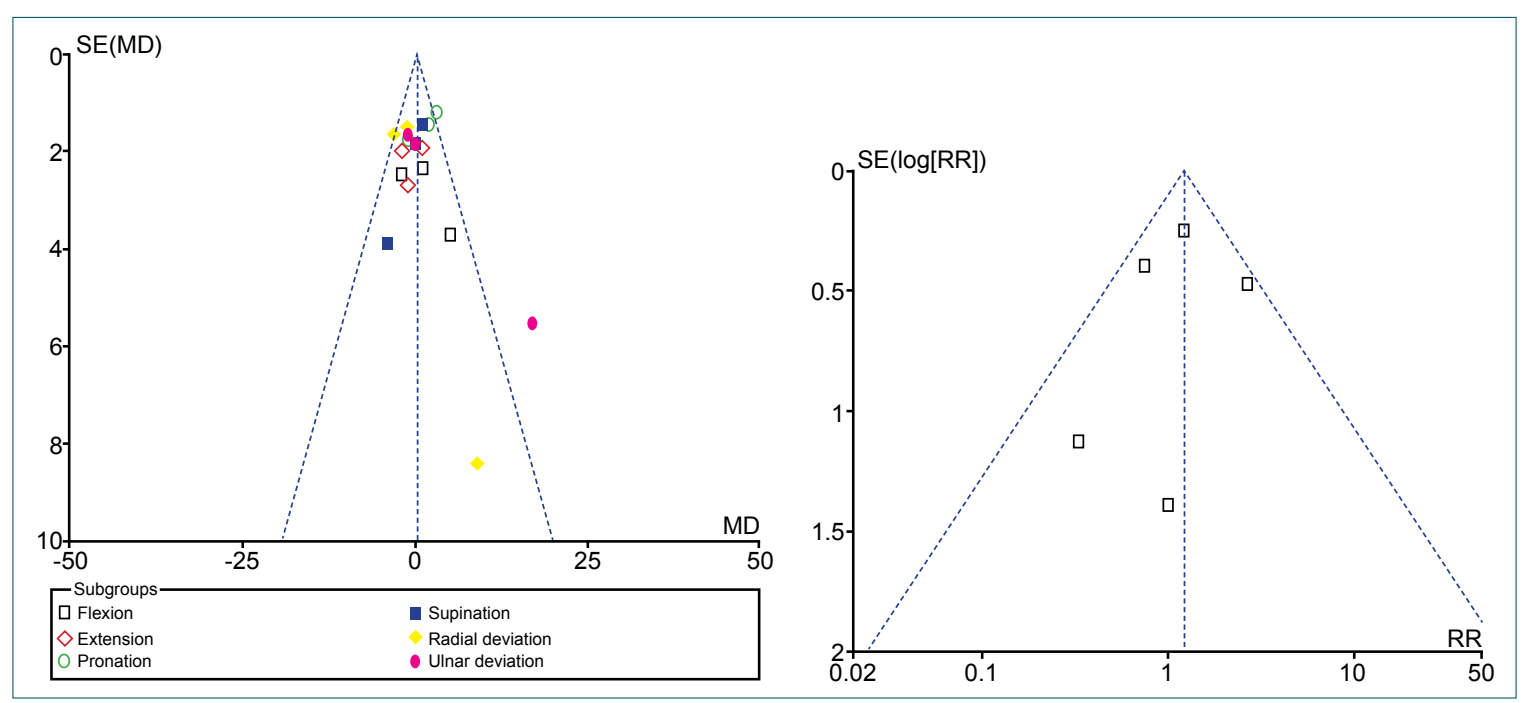

Figure 8. Funnel plots analysis.

concern. However, in the process of selecting literature and extracting data, the meta-analysis was in strict accordance with relevant requirements. Funnel plot analysis revealed no evidence of publication bias (Fig. 8).

\section{DISCUSSION}

Pooled results with significant heterogeneity from the present meta-analysis of 10 RCTs suggested that patients undergoing conservative treatment for distal radius fractures had better restoration of pronation, but shorter restoration of radial length. Wrist range of motion other than pronation, grip strength, radiographic parameters other than radial length, and rate of complication were not found to be significantly different between the 2 treatments.

In spite of the frequent incidence of distal radius fractures, optimal treatment remains controversial. ${ }^{[21]}$ Zyluk $A$ et al. ${ }^{[22]}$ concluded that conservative treatment of distal radius fractures should be confined only to non- or minimally-displaced fractures, and that all other patients with exceeding acceptable dislocation were candidates for surgery. Some authors concluded that best treatment option is dependent on type of fracture, extent of metaphyseal comminution, quality of the bone, and the medical condition of the patient. ${ }^{[23]}$ Others concluded that conservative treatment remains the safest option in most cases. ${ }^{[4]}$ In the present meta-analysis, no significant difference between internal fixation and conservative treatment were found. It was presently concluded that closed reduction and plaster immobilization are the best treatment of distal radius fracture. Nonetheless, surgical treatment is recommended if fracture redisplacement has occurred. ${ }^{[25]}$ At the same time, the authors believe that a scoring system is a valuable decision-making tool. ${ }^{[26]}$

Distal radius fractures are the most common fracture of the upper extremity and cause variable disability. ${ }^{[2]}$ Evaluation of treatment options is in dispute. Some clinicians believe that ulnar variance and volar tilt are the most important radiographic parameters to be restored, in order to obtain good functional outcome, and that small variations in other radiographic parameters seem not to affect the final outcome in short-term follow-up. ${ }^{[28]}$ The ability of volar locked plating to restore and maintain ulnar variance and volar tilt decreases in more complex fracture types. ${ }^{[29]}$ Treatment of unstable distal radius fractures with volar locked plating and without additional bone graft leads to good fracture reduction without significant secondary displacement. ${ }^{[30]}$ However, Lutz $\mathrm{K}$ et al. found that elderly patients with distal radius fractures who underwent surgery had higher rates of complication than those nonsurgically treated. ${ }^{[3]}$ Approximately $2 \%$ of patients sustained complication within 30 days following open reduction and internal fixation. ${ }^{[32]}$ Nevertheless, results of the present meta-analysis suggested that there were no significant differences in complication rates between the internal fixation groups and the conservative treatment groups. Regardless of the method of reduction and stabilization, early restoration of wrist function is the goal of distal radius fracture treatment.

Several potential limitations may have affected the present meta-analysis. Ten RCTs were included, but 3 were of low quality (Jadad score <4). The number of cases was small, with a lack of adequate data for analysis. Second, the meta-analysis did not reveal differences in effects specific to fracture type or patient age, due to the limited number of trials. Finally, the performance of activities of daily living, vocational function, and economic impact parameters were not presently discussed, due to lack of reported data.

Generally speaking, the present results are reliable, in spite of the limitations. Clinical differences among patients who received internal fixation and those who received conservative treatment were very slight, although an increase in distal ra- 
dius fracture incidence and number of surgeries has been reported. ${ }^{[33,34]}$ Further verification in higher-quality trials is warranted. In such future studies, long-term outcomes should be more carefully considered, more detailed information regarding fracture type should be provided, and explicit concerns regarding patient age should be taken into consideration.

\section{Conclusions}

Very little clinical difference was found between patients who underwent internal fixation and conservative treatment for displaced distal radius fractures. Optimal choice of treatment must depend upon concrete conditions.

\section{Conflict of interest: None declared.}

\section{REFERENCES}

1. Nellans KW, Kowalski E, Chung KC. The epidemiology of distal radius fractures. Hand Clin 2012;28:113-25. Crossref

2. Neidenbach P, Audigé L, Wilhelmi-Mock M, Hanson B, De Boer P. The efficacy of closed reduction in displaced distal radius fractures. Injury 2010;41:592,8.

3. Chung KC, Shauver MJ, Birkmeyer JD. Trends in the United States in the treatment of distal radial fractures in the elderly.J Bone Joint Surg Am 2009;91:1868-73. Crossref

4. Mattila VM, Huttunen TT, Sillanpää P, Niemi S, Pihlajamäki H, Kannus $P$. Significant change in the surgical treatment of distal radius fractures: a nationwide study between 1998 and 2008 in Finland. J Trauma 2011;71:939-43. Crossref

5. Lichtman DM, Bindra RR, Boyer MI, Putnam MD, Ring D, Slutsky DJ, et al. American Academy of Orthopaedic Surgeons clinical practice guideline on: the treatment of distal radius fractures. J Bone Joint Surg Am 2011;93:775-8. Crossref

6. Cui Z, Pan J, Yu B, Zhang K, Xiong X. Internal versus external fixation for unstable distal radius fractures: an up-to-date meta-analysis. Int Orthop 2011;35:1333-41. Crossref

7. Esposito J, Schemitsch EH, Saccone M, Sternheim A, Kuzyk PR. External fixation versus open reduction with plate fixation for distal radius fractures: a meta-analysis of randomised controlled trials. Injury 2013;44:409-16. Crossref

8. Cui Z, Yu B, Hu Y, Lin Q, Wang B. Dynamic versus static external fixation for unstable distal radius fractures: an up-to-date meta-analysis. Injury 2012;43:1006-13. Crossref

9. Handoll HH, Huntley JS, Madhok R. External fixation versus conservative treatment for distal radial fractures in adults. Cochrane Database Syst Rev 2007;3:CD006194. Crossref

10. Oremus M, Wolfson C, Perrault A, Demers L, Momoli F, Moride Y. Interrater reliability of the modified Jadad quality scale for systematic reviews of Alzheimer's disease drug trials. Dement Geriatr Cogn Disord 2001;12:232-6. Crossref

11. Azzopardi T, Ehrendorfer S, Coulton T, Abela M. Unstable extra-articular fractures of the distal radius: a prospective, randomised study of immobilisation in a cast versus supplementary percutaneous pinning.J Bone Joint Surg Br 2005;87:837-40.

12. Arora R, Lutz M, Deml C, Krappinger D, Haug L, Gabl M. A prospective randomized trial comparing nonoperative treatment with volar locking plate fixation for displaced and unstable distal radial fractures in patients sixty-five years of age and older.J Bone Joint Surg Am 2011;93:2146-53.

13. Wong TC, Chiu Y, Tsang WL, Leung WY, Yam SK, Yeung SH. Casting versus percutaneous pinning for extra-articular fractures of the distal radius in an elderly Chinese population: a prospective randomised controlled trial. J Hand Surg Eur Vol 2010;35:202-8. Crossref

14. Gupta R, Raheja A, Modi U. Colles' fracture: management by percutaneous crossed-pin fixation versus plaster of Paris cast immobilization. Orthopedics 1999;22:680-2.

15. Stoffelen DV, Broos PL. Closed reduction versus Kapandji-pinning for extra-articular distal radial fractures. J Hand Surg Br 1999;24:89-91.

16. Rodríguez-Merchán EC. Plaster cast versus percutaneous pin fixation for comminuted fractures of the distal radius in patients between 46 and 65 years of age. J Orthop Trauma 1997;11:212-7. Crossref

17. Miller BS, Taylor B, Widmann RF, Bae DS, Snyder BD, Waters PM. Cast immobilization versus percutaneous pin fixation of displaced distal radius fractures in children: a prospective, randomized study. J Pediatr Orthop 2005;25:490-4. Crossref

18. Diao HH. Comparative efficacy of the two treatment methods in elderly patients with Colles fracture. Hainan Med J 2013;24:3069-71.

19. $\mathrm{Li} \mathrm{JQ}, \mathrm{Li} Z \mathrm{ZQ}$. Clinical research of open reduction and closed reduction in the treatment of elderly distal radial fractures. Chinese Journal of New Clinical Medicine 2012;5:843-5.

20. Hu YX. The Efficacy of T-plate Internal Fixation in the Treatment of Distal Radius Fractures. Journal of Ningxia Medical University 2012;34:822-4.

21. Schneppendahl J, Windolf J, Kaufmann RA. Distal radius fractures: current concepts. J Hand Surg Am 2012;37:1718-25. Crossref

22. Zyluk A, Puchalski P, Walaszek I, Janowski P. A reasonable algorithm for treatment of distal radius fractures. [Article in Polish] Chir Narzadow Ruchu Ortop Pol 2010;75:10-6. [Abstract]

23. Cherubino P, Bini A, Marcolli D. Management of distal radius fractures: treatment protocol and functional results. Injury 2010;41:1120-6. Crossref

24. Trevisan C, Klumpp R, Nava V, Riccardi D, Recalcati W. Surgical versus conservative treatment of distal radius fractures in elderly. Aging Clin Exp Res 2013;25 Suppl 1:83-4. Crossref

25. Walenkamp MM, Goslings JC, Beumer A, Haverlag R, Leenhouts PA, Verleisdonk EJ, et al. Surgery versus conservative treatment in patients with type A distal radius fractures, a randomized controlled trial. BMC Musculoskelet Disord 2014;15:90. Crossref

26. Kodama N, Imai S, Matsusue Y. A simple method for choosing treatment of distal radius fractures. J Hand Surg Am 2013;38:1896-905. Crossref

27. Tahririan MA, Javdan M, Nouraei MH, Dehghani M. Evaluation of instability factors in distal radius fractures. J Res Med Sci 2013;18:892-6.

28. Dario P, Matteo G, Carolina C, Marco G, Cristina D, Daniele F, et al. Is it really necessary to restore radial anatomic parameters after distal radius fractures? Injury 2014;45 Suppl 6:21-6. Crossref

29. Mignemi ME, Byram IR, Wolfe CC, Fan KH, Koehler EA, Block JJ, et al. Radiographic outcomes of volar locked plating for distal radius fractures. J Hand Surg Am 2013;38:40-8. Crossref

30. Ayong S, Traore A, Postlethwaite D, Barbier O. Functional evaluation of unstable distal radius fractures treated with an angle-stable volar T-plate. Acta Orthop Belg 2014;80:183-9.

31. Lutz K, Yeoh KM, MacDermid JC, Symonette C, Grewal R. Complications associated with operative versus nonsurgical treatment of distal radius fractures in patients aged 65 years and older. J Hand Surg Am 2014;39:1280-6. Crossref

32. Jiang JJ, Phillips CS, Levitz SP, Benson LS. Risk factors for complications following open reduction internal fixation of distal radius fractures. J Hand Surg Am 2014;39:2365-72. Crossref

33. Mattila VM, Huttunen TT, Sillanpää P, Niemi S, Pihlajamäki H, Kannus P. Significant change in the surgical treatment of distal radius fractures: a nationwide study between 1998 and 2008 in Finland. J Trauma 2011;71:939-3. Crossref

34. Koo OT, Tan DM, Chong AK. Distal radius fractures: an epidemiological review. Orthop Surg 2013;5:209-13. Crossref 


\section{ORİJINAL ÇALIŞMA - ÖZET}

\section{Deplase distal radius kırıklarında internal fiksasyona karşın konservatif tedavi: Randomize kontrollü çalışmaların metaanalizi \\ Dr. Guang-Shu Yu, ${ }^{1}$ Dr. Yan-Bin Lin, ${ }^{1}$ Dr. Li-Sheng Le, ${ }^{2}$ Dr. Mei-Feng Zhan, ${ }^{3}$ Dr. Xiao-Xiang Jiang ${ }^{4}$}

${ }^{1}$ Xia Men Üniversitesi, Fuzhou İkinci Hastanesi, Ortopedi ve Travmatoloji Kliniği, Fu Zhou, Fujian-Çin

${ }^{2}$ Fuzhou İkinci Hastanesi Mawei Şubesi, Ortopedi ve Travmatoloji Kliniği, Fu Zhou, Fujian-Çin

${ }^{3}$ Luoyuan İlçe Hastanesi, Ortopedi ve Travmatoloji Kliniği, Fujian-Çin

${ }^{4}$ Fujian Üniversitesi, Geleneksel Çin Tıbbı Yüksek Okulu, Fujian-Çin

AMAÇ: Deplase distal radius kırıklarında internal fiksasyona karşın konservatif tedavinin klinik sonuçlarını karşılaştırmak.

GEREÇ VE YÖNTEM: Yapılan çalışma sonuçları PubMed, Cochrane Library, EMBASE, BIOSIS, Ovid veri tabanları ile CNKI ve Wanfang veri tabanından derlendi. Çalışmaların metodolojik kalitesi eleştirel açıdan değerlendirildi ve ilgili veriler çıkartıldı. Veri analizi için istatistiksel Revman 5.0 yazılımı kullanıldı.

BULGULAR: Çalışmaya katılımı uygun görülen toplam 653 hastayı kapsayan randomize kontrollü yedi İngiliz ve üç Çin çalışmasının metaanalizi yapıldı. Çalışmaların sonuçları orta derecede yanılgı payına sahipti. Metaanaliz sonuçları distal radius kırıkları için konservatif tedavi gören hastalarda pronasyonun daha iyi (MD= I.80; \%95 GA: 0. 18-3.42; $p=0.03$; heterojenite $p=0.17 ; 12=\% 43)$ sağlandığını, ancak radius boyunun daha kısa kaldığını gösterdi (MD=2.62; \%95 GA: I.47-3.76, $p<0.0000$ I; heterojenite $p=0.02 ; 12=\% 73)$. Pronasyon dışında el bileğinin hareket erimi, kavrama gücü, radius uzunluğu dışındaki radyografik parametreler ve komplikasyon oranları iki tedavi grubu arasında anlamlı derecede farklı değildi.

TARTIŞMA: Deplase distal radius kırıklarının tedavisinde internal fiksasyon ile konservatif tedavi arasında çok az klinik farklılı olduğu gibi en iyi tedavi seçeneğinin somut koşullara göre kararlaştırılması gerekmektedir.

Anahtar sözcükler: Distal radius kırıkları; internal fiksasyon; konservatif tedavi; metaanaliz.

Ulus Travma Acil Cerrahi Derg 20I6;22(3):239-24I doi: 10.5505/tjtes.20I5.05995 